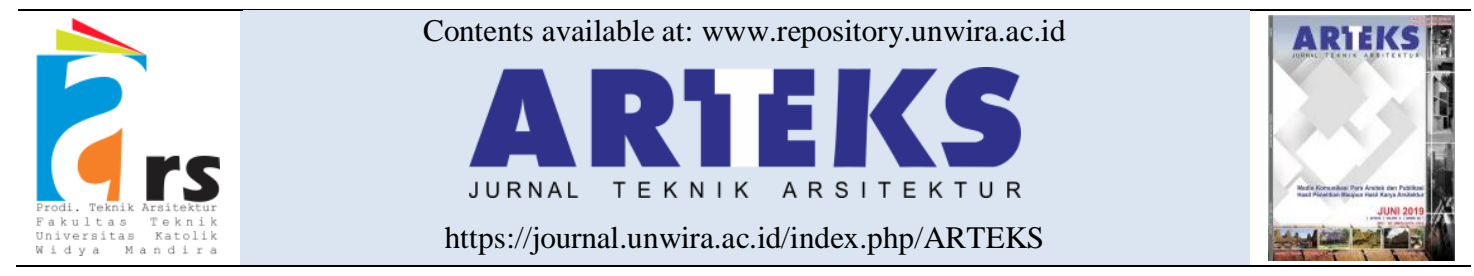

Research paper

doi: 10.30822/arteks.v5i3.536

\title{
The relationship between traditional activities and the mass-space pattern in Bali Aga Customary Village society - Tenganan Pegringsingan
}

\author{
Lydia Dewi Setiawan, Purnama Salura*(1), Bachtiar Fauzy \\ Architecture Study Program, Faculty of Engineering, Universitas Katolik Parahyangan \\ Jl. Ciumbuleuit no. 94, Bandung, Indonesia
}

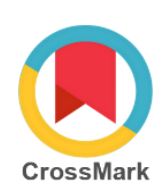

\begin{tabular}{l}
\hline ARTICLE INFO \\
\hline Article history: \\
Received May 18, 2020 \\
Received in revised form June 23, 2020 \\
Accepted July 26, 2020 \\
Available online December 01, 2020
\end{tabular}

Keywords:
Customary Village Bali Aga
Mass-space pattern
Relation
Society traditional activity

*Corresponding author: Purnama Salura Architecture Study Program, Faculty of Engineering, Universitas Katolik Parahyangan, Indonesia

Email: purnamasalura.ps@unpar.ac.id

ORCID: https://orcid.org/0000-0002-3652-

7192

\begin{abstract}
Globalization is being experienced throughout the world with its impact also observed in architecture, even in traditional villages of Indonesia. Some of them have, however, been able to maintain their identity such as the mass-space pattern of the customary village of Bali Aga Mountains in Bali which is discovered not to have changed. This research was, therefore, conducted to determine the relationship between the activities of the traditional society and their mass-space patterns using the customary village of Bali Aga Tenganan Pegringsingan as the case study. This involved the selection of respondents purposively and collection of data using cross sections by identifying unchanged buildings, taking photos, videos, drones, and through direct interviews in the field. The data obtained were analyzed qualitatively based on structuring theory or ordering principles and the results confirmed the mass-space pattern in Tenganan Pegringsingan village was built due to the close relations with the traditional activities of the society. The findings can be used in developing architecture by local governments as policymakers as well as academic architects and practitioners, and the wider society.
\end{abstract}

\section{Introduction}

Austronesian culture originated from the people recorded to have lived along the rivers of South China and North Vietnam in the middle of the 4th century BC (Noerwidi 2018). One of their inheritance is the residential architecture which serves as an identity and social position in the society (Sahroni 2012). The Austronesian architecture is known as Indonesian vernacular architecture (Penny 1987) and it was explained in the book Encyclopedia of Vernacular Architecture by Paul Oliver to have been built using local resources by local people and with simple technology (Nabakov and Nabokov 1999).
It is, therefore, possible to interpret vernacular architecture as the original architecture built by the local community (Oliver 1998). One of the attributes of these in Indonesian is the settlement environment characterized by the traditional society (Sahroni 2012). This involves understanding mass and space patterns in accordance with the traditional values of the society in order to accommodate, respect, and maintain the existence of villages, as a form of national cultural identity preservation (Antariksa 2018).

The concept of globalization influences culture, including those related to architecture, as observed with the erosion of national identity 
through designs with almost the same shape for structures in major cities throughout the world (Hidayatun, Prijotomo, and Rachmawati 2014b). This is also evident in customary villages of Indonesia, especially those with tourism potentials with the functions, shapes, building materials, and other buildings being added found not to be suitable with the traditional mass-space pattern (Kumurur and Damayanti 2011). The positive impact of globalization is, however, evident in the attitude of the society in maintaining the uniqueness of its customary villages (Hidayatun, Prijotomo, and Rachmawati 2014a).

According to the Minister Regulation of Culture and Tourism No. PM.26/UM.001/MKP/2010, March 18th, 2010, the customary villages used for tourism in Indonesia include Ke'te Kesu-Tana Toraja, Wae Rebo Village-East Nusa Tenggara, Praijing and Ratenggaro Villages-Southwest Sumba-NTT, Nagari Pariangan-West Sumatra, Torosiaje Villages-Gorontalo, Baduy Customary VillagesBanten and several others in Bali (Menteri Kebudayaan dan Pariwisata RI 2010). Meanwhile, those in Bali have been observed to have the easiest achievement as indicated by a large number of tourist visits and this further exposes the communities to globalization influence (Budihardjo 2019). It is, however, important to study this area due to the fact that some customary Balinese villages have not experienced significant changes due to outside influences (Kumurur and Damayanti 2011). Those maintaining the cultural tradition include Bali Mula or Bali Aga which has been existing for more than 1100 years without been influenced by Majapahit but the influence is observed in Bali Apanaga. Bali Aga does not know Meru which is a sacred building with a multi-story roof and their worship place is like the stones of the megalithic era (Bali Teen Adventure 2015). The people worship ancestral spirits they believed are protecting them and this has led to the construction of menhirs (pillars or stone pillars), punden berundak (stone with pyramidal structure), stone statues, and dolmen or altar for worship (Soeriadiredja and Aliffiati 2017).

The concepts in Bali Aga Village are very rare in contrast to those observed in Bali Apanaga Village which are popular up to the present time (Agusintadewi and Manik 2016). According to Ngakan Ketut Acwin Dwijendra, Bali Aga is the ancient or original Bali before the Bali Apanaga
(Dwijendra 2009) and one of its most visible features is the death ceremony which involves being buried and not knowing ngaben (Widiastuti 2018). It is, therefore, important to explore this village in order to fill the treasury void in the relation between activities and mass-space patterns.

This research was conducted to study the relationship between traditional social activities related to customs, religion and mass-space patterns, especially those in the mountains, in the customary village of Bali Aga. The areas selected for this research were ensured to have met the following criteria: (1) Represent the Bali Aga village; (2) located in the mountains; (3) has been around for a long time, 700-800 years old; and (4) the buildings currently being inhabited with the livelihood maintained.

One of the villages with these criteria is the Tenganan Pegringsingan (Tenganan Pegringsingan Customary Village) and observed to be existing with reference to the traditional rules and customs inherited from their ancestors (Kumurur and Damayanti 2011). The shape and arrangement of the building, yard, and temple are in line with the customary rules which have been maintained for generations. The daily activities are also being governed by the customary law known as the awig-awig (Sumunar, Suparmini, and Setyawati 2017).

Tenganan Pegringsingan Customary Village is located in one Tenganan service environment in Manggis District, Karangasem Regency Level II, $\pm 18 \mathrm{~km}$ from Amlapura city or $\pm 67 \mathrm{~km}$ from Denpasar City, $3 \mathrm{~km}$ from the sea to the North, with an altitude of $70 \mathrm{~m}$ above sea level and temperature $28^{\circ} \mathrm{C}$. It is specifically located in the valley between three hills which are the Bukit Kangin in the East, Bukit Kaja in the North, and Bukit Kauh in the West (figure 1; figure 2). Some other villages on its boundaries include:

- Bebandem at its North

- Nyuh Tebel and Pasedahan at the South

- Ngis at the West

- Karang Asem Subdistrict at the East

The total area is 894.88 ha consisting of 583.04 uplands, 255.85 ha rice fields, and 8 ha settlements (Runa 2018). 


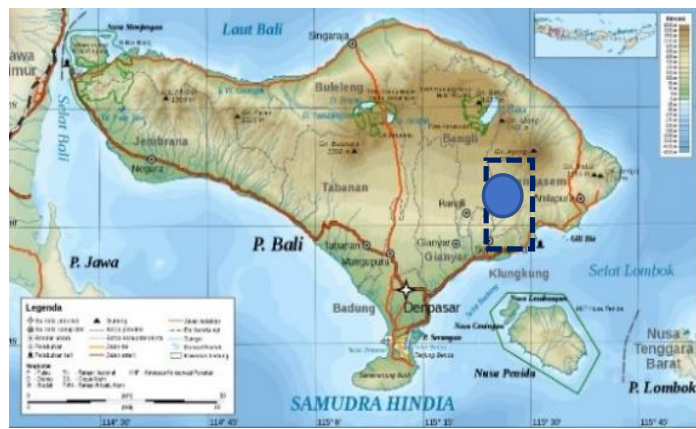

Figure 1. The map of Balinese Tenganan Pegringsingan Village

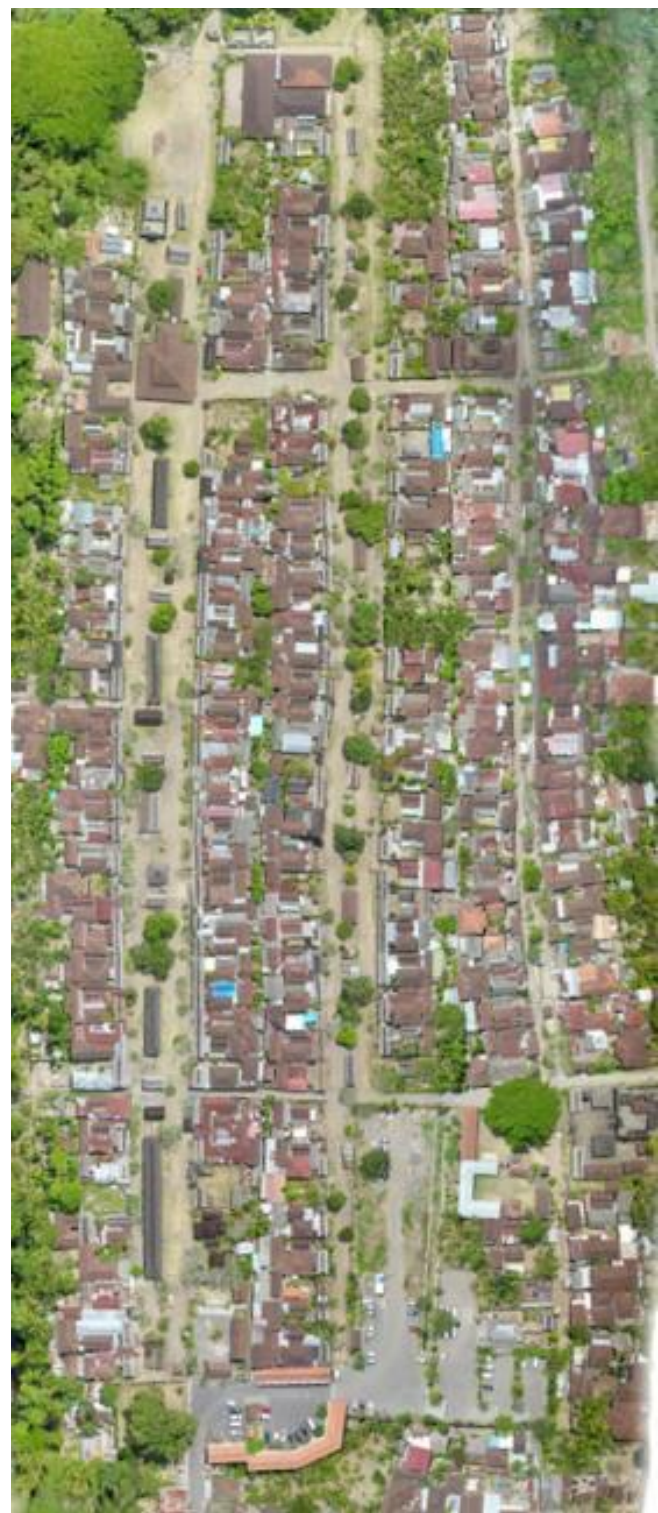

Figure 2. Photograph of Tenganan Pegringsingan Village by drone

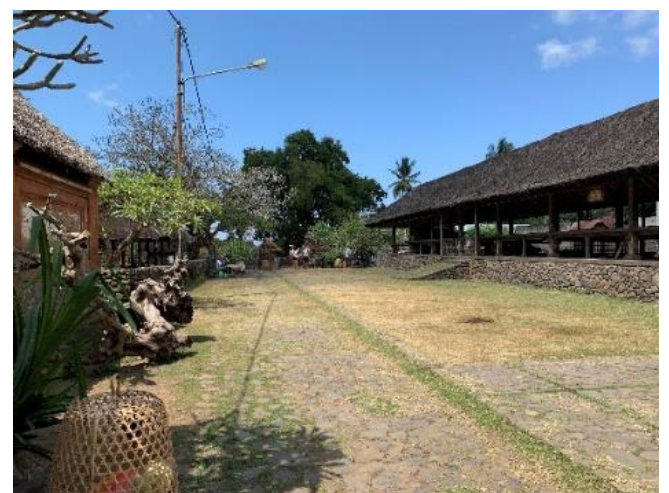

Figure 3. Situation of Tenganan Pegringsingan

The research question to be answered is "what significant concept underlies the formation of Bali Aga traditional village pattern in Tenganan Pegringsingan Village based on the study of property and composition theory?"

This study was conducted to uncover the relationship between traditional society activities and the mass-space pattern of Bali Aga Customary Village in Tenganan Pegringsingan village. The focus was on intended traditional activities such as mekare-kare, wedding, and death ceremonies (Yanuarta, Ermawati, and Kusrini 2019).

The findings of this research are expected to be used as an academic reference regarding the relationship between activities and mass-space patterns in Bali Aga Customary Village in Tenganan Pegringsingan village. It is also possible to use them as a foundation for architects or practitioners in designing residential environments related to the Bali Aga customary village mass-space pattern. Moreover, it can also be applied in developing structuring patterns of settlement arrangements related to the mass-space pattern conceptual tradition as well as in ensuring traditional Balinese architecture survival. It can also serve as a guide for traditional architecture observers in Indonesia.

\section{Method}

In line with the objectives of this study, the following stages were followed as the method to conduct the research:

1. Data collection:

- Samples were selected purposively based on certain criteria including, buildings considered to be old, those that have not 
changed much, and those which materials have been changed;

- Data were selected using cross-section and this involved assessing facts in the field and discovering empirical phenomena or experience of Tenganan Pegringsingan Customary Village related to society's traditional activities;

- Field data were obtained through (a) aerial photographs (drones), (b) photographs and videos, (c) interviews to have an overview of the history and culture of the village, and (d) site and building measurements.

2. Analysis:

- Descriptive method was used by describing literature studies and field interview data;

- Interpretative method was also employed and this involved (a) describing the background of the problem, (b) determining the phenomenon of globalization impact process in Balinese Aga customary village, (c) formulating research problems related to the relationship between traditional society activities and the mass-space pattern of Bali Aga Customary Village, Tenganan Pegringsingan, and (d) analyzing data with architectural anatomy and ordering principles theories from Purnama Salura (Salura 2018) which include property and composition of the environment and site scope (Salura 2010), associated with the analysis of interviews on traditional activities with village and site properties to determine the relationship between the two.

\section{Result and discussion}

In accordance with the steps previously outlined, the Tenganan Pegrisingan Village was observed to have a physical property based on the surrounding environment and site scopes as shown in figure 4.

It was further analyzed with architectural anatomy and structuring principles theories (Salura 2018) using the results of the interviews with the residents.

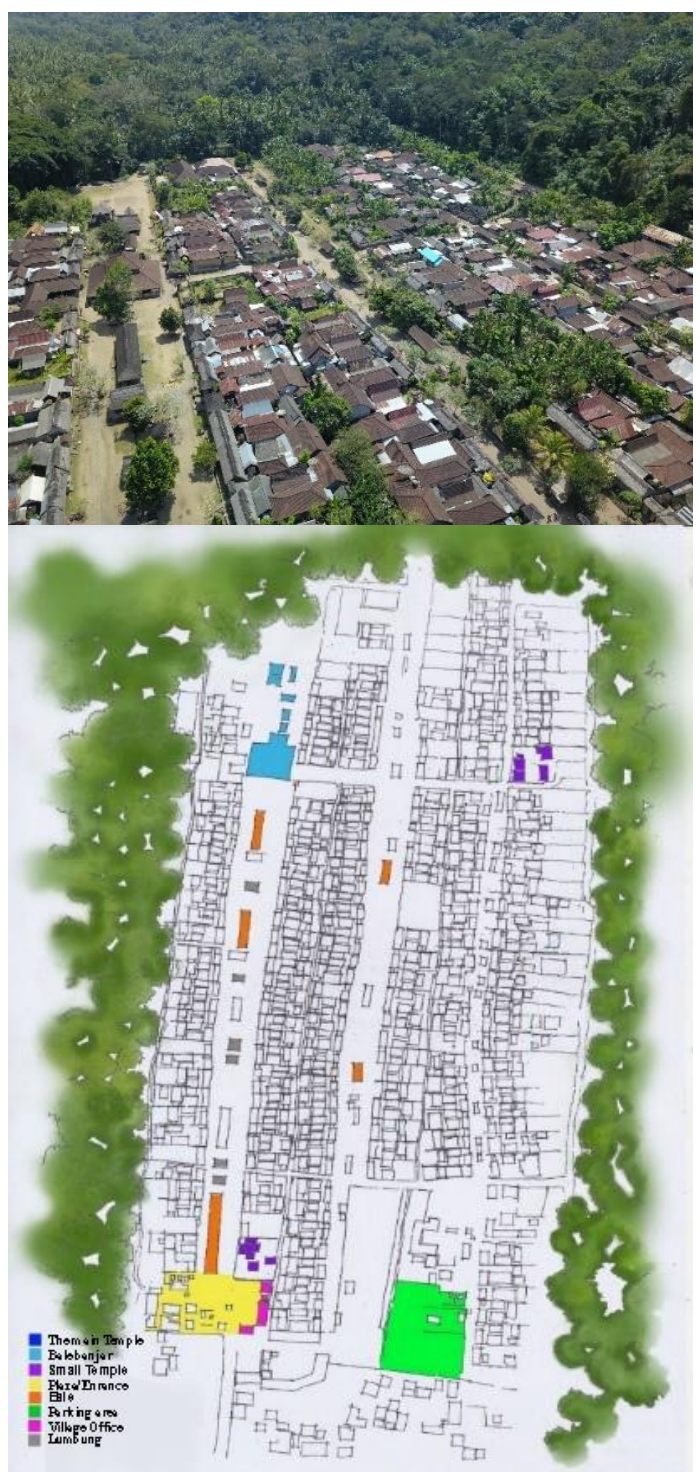

Figure 4. Property of Tenganan Pegringsingan Village

\section{The surrounding environment scopes}

The properties observed in the surrounding environment of the village include (1) forest, (2) Temples, (3) Bale including agung, kulkul, jineng, banjar, petemu kelod, and glebeg, (4) roads, (5) archway, (6) karang/footprint, (7) open space, and (8) graves/tombs.

The scope was observed to be closed, bounded by forests on the left or west, right or east, and front or north. The village is positioned in the valley with its bottom or south being the highway.

There are two temples including Kawitan or Dalem Temple located on the lower side or south as shown in figure 5 and Panyawangan Temple 
located on the top or North which are constructed for religious activities in the village.

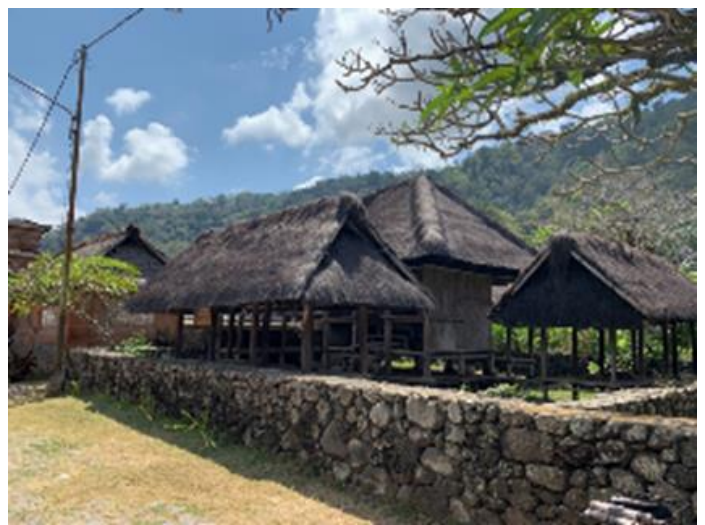

Figure 5. Kawitan Temple

Bale is the gathering place for joint activities or deliberations and observed to have been located as public facilities in the form a row in the middle road as shown in figure 6 . They, however, perform different functions with agung used for religious activities attended by married people, kulkul to strike kentongan, jineng to save rice yields, banjar to gather or consult, petemu kelod serving as gathering place for young people, and glebeg functioned as storage for harvests from customary villages before it was converted to be used for xylophone music activity. The bale is located along the row site and this makes it very close to the karang.

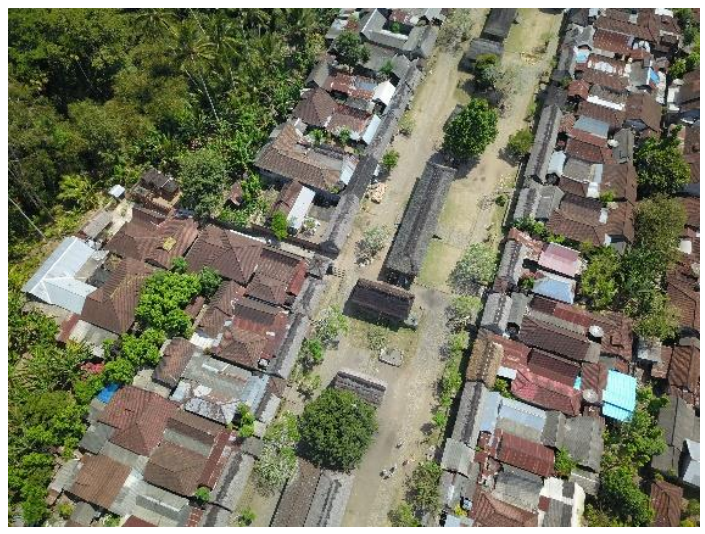

Figure 6. Bale as public facility along the road of Tenganan Pegringsingan Customary Village

The road in Tenganan Pegringsingan is the village core functioning as an open space for religious activities and traditional ceremonies. It is linearly patterned from the bottom or South to the top or North with two lanes in the form of the main and secondary, as well as a connecting road between them. There is another tertiary road which is being used as an access to the site or karang from the back. It is more private and also used as a circulation path for repelled religious events as shown in figure 7.

From the hierarchy or composition perspective, the structures are observed to be higher as they move upward or towards the North and this is evident with the use of fewer stairs to enter the karang at the upper part of the village as shown in figure 8.

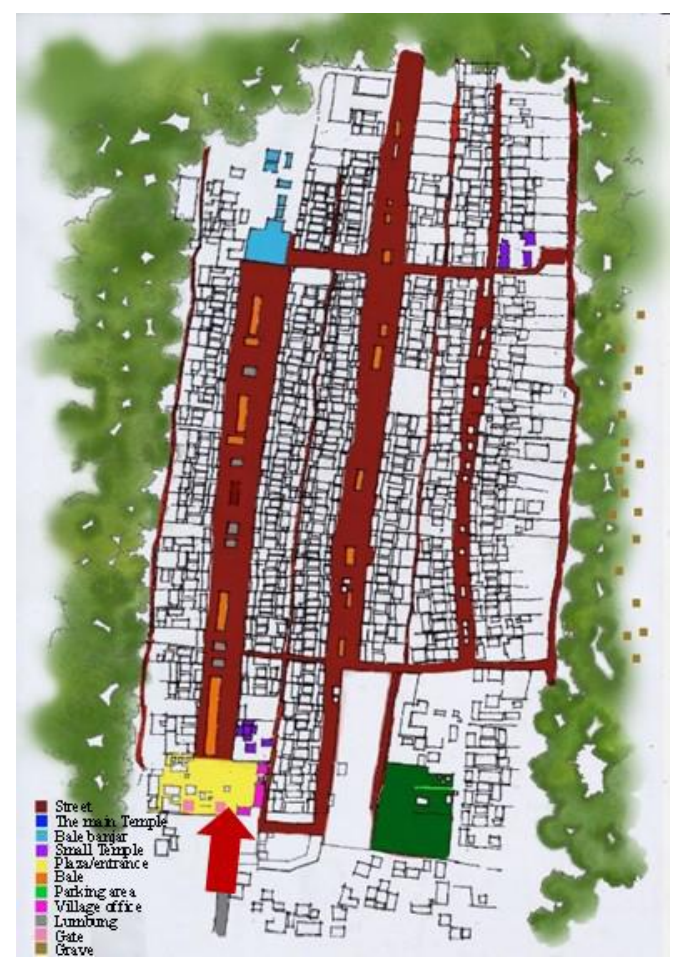

Figure 7. Linear circulation of roads in Tenganan Pegringsingan Customary Village 


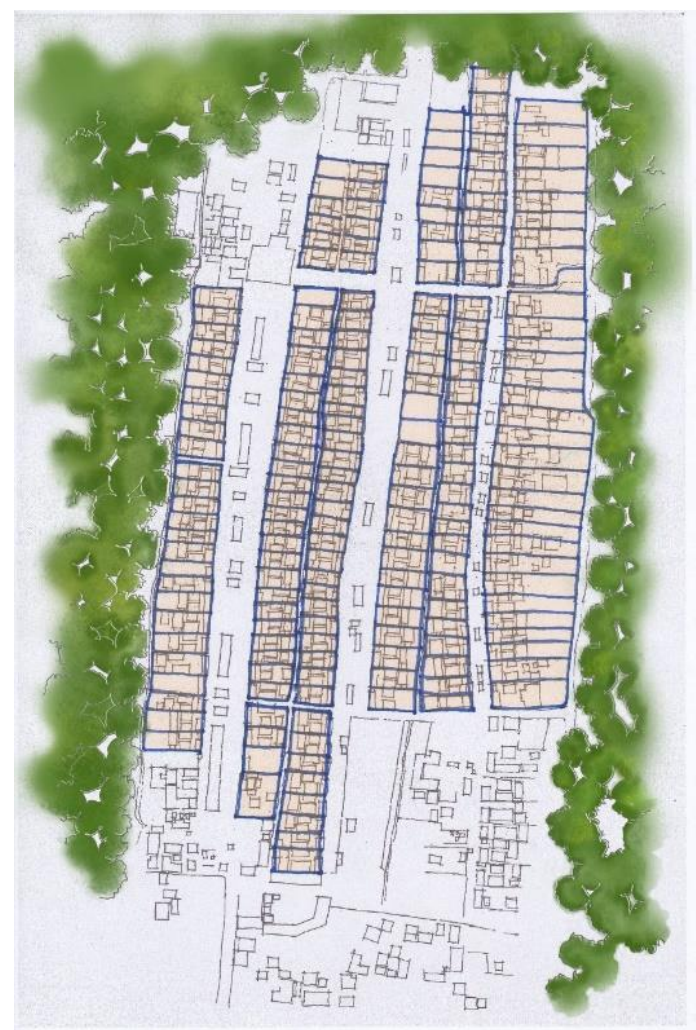

Figure 8. Rows of karang/site in Tenganan Pegringsingan Customary Village

The entrance to the village is on the south side or below without any special shape but only an opening hole which is used as a sign. There are two side doors with one located on the left or west to the garden and another on the right or East to the tomb.

The rows of the site facing the main road mean the entrance to karang faces West and East with the space between the house wall and road called awangan. Moreover, the position of karang in the row is contradictorily separated at the back by the teba or tertiary road. The entrance from the front and back of the house is in one axis and the boundary is enclosed by a wall in the form of a high rock (penyengker) surrounding the site.

It can be concluded that Tenganan Pegringsingan Village has a linear pattern with the North-South axis and the East-West (KanginKauh) sunrise-East and sunset-West concepts (figure 9).

The village is also divided into several zones with the East-West (Kangin-Kauh) having three which are (1) Kauh Banjar Customary (Westside) or public zone, (2) Central Indigenous Banjar or semi-private zone, and (3) East Pande Banjar Customary (East side) or private zone.

Banjar has two which include the private zone as well as the main road and facilities which are generally public (figure 10).

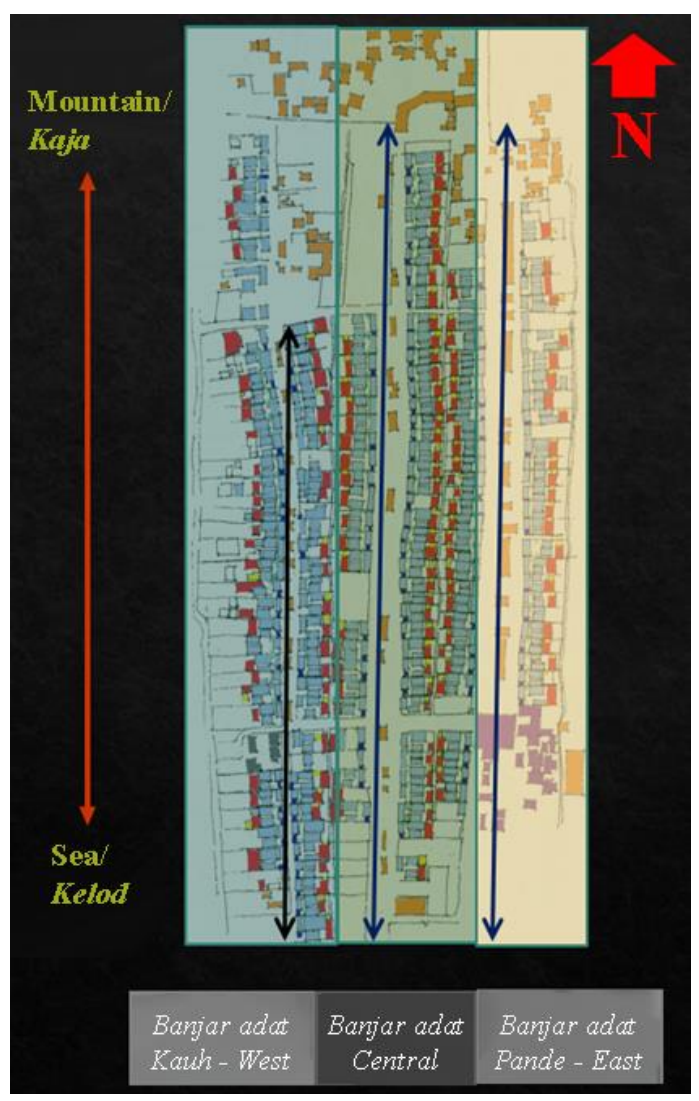

Figure 9. Banjar customary zone (Kangin-Kauh) 


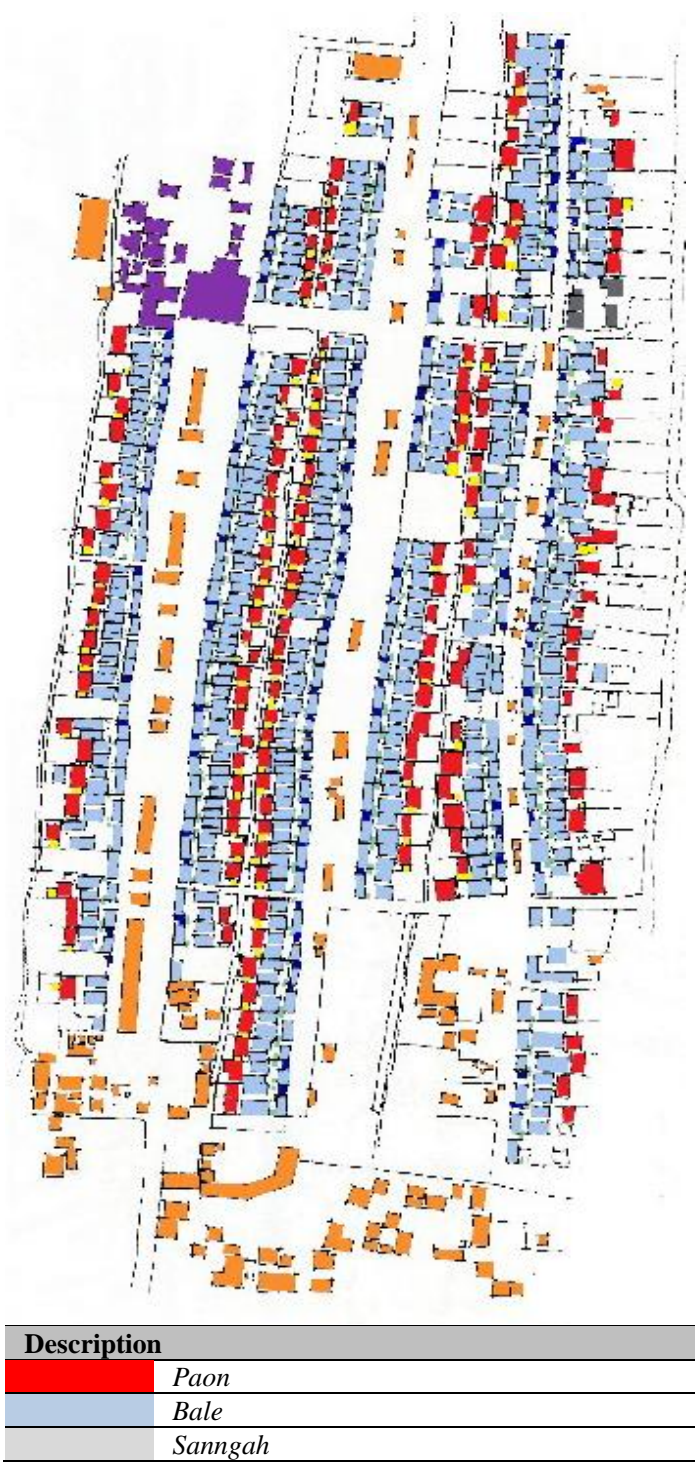

Figure 10. The mass of building in Tenganan Pegringsingan Traditional Village

The high walls along the left and right of the road in the village create a linear open space pattern in the form of a road axis from the bottom or South to the top or North which is usually used for religious and traditional ceremonies as shown in figure 11. It also functions as a public facility for meetings and other social activities as indicated in figure 12. Moreover, the plaza in the middle zone is bigger than the plaza in the Banjar Kauh or West zone and the smallest is the Banjar Kangin open space zone in the East as presented in figure 13.

The tomb is located in the East outside the village and its entrance is higher than the area with approximately 2-meter distance from the ground level. This means after reaching the height of the entrance, there is a need to walk down to the valley where the burial area is located. In principle, the tomb is positioned lower than the Tenganan Pegringsingan Customary Village.

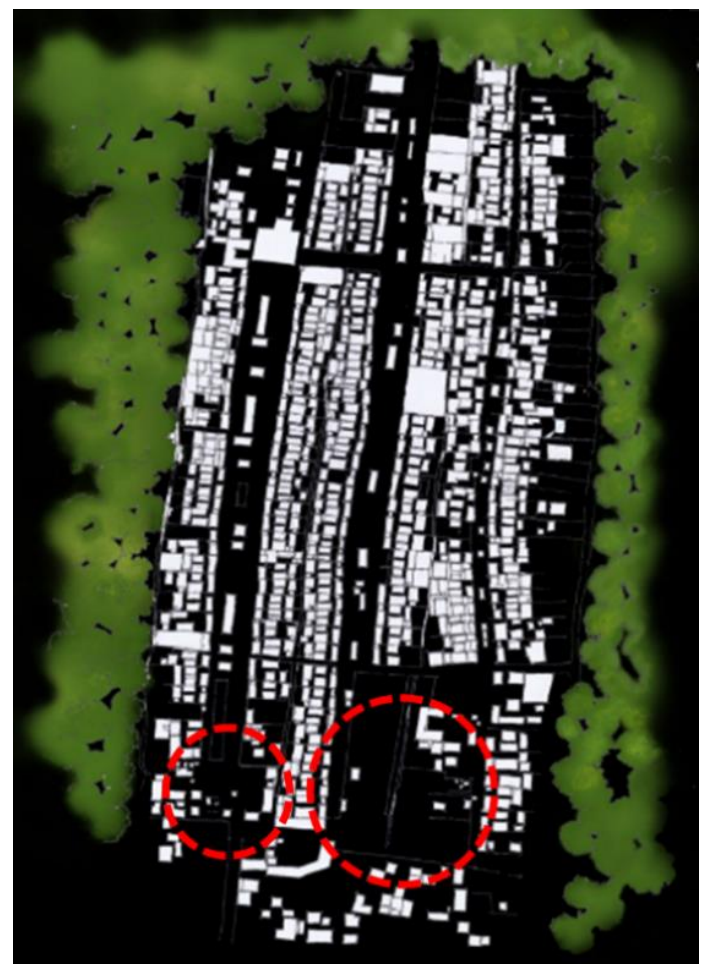

Figure 11. Village open space 

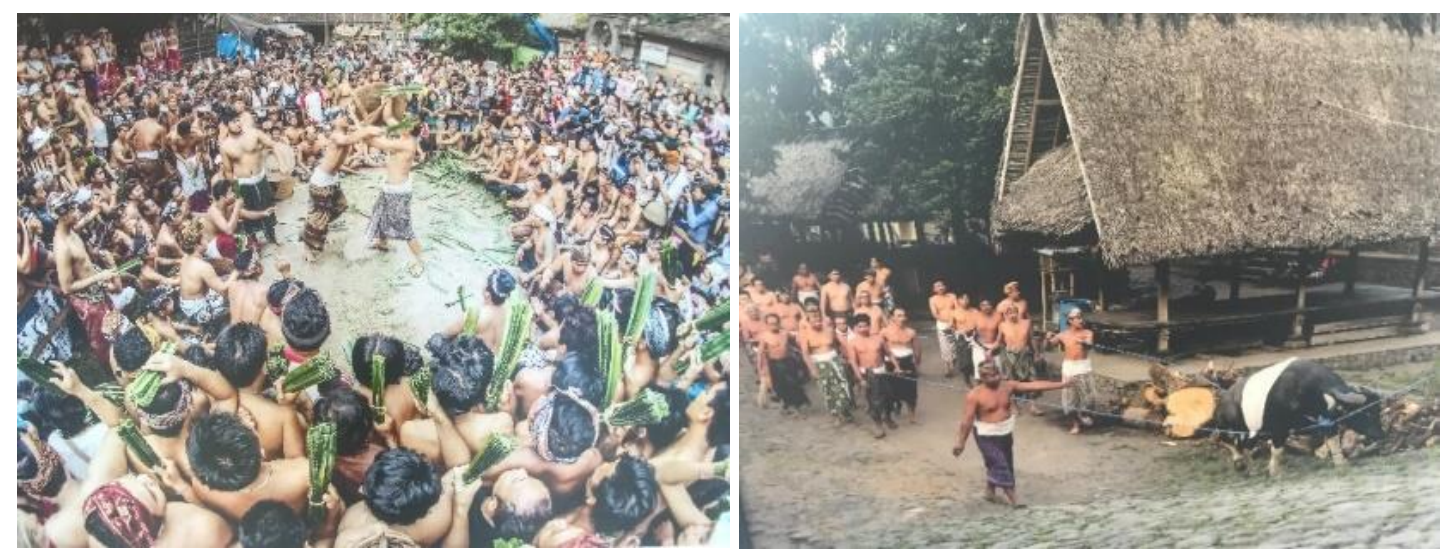

Figure 12. Traditional activities in the open space
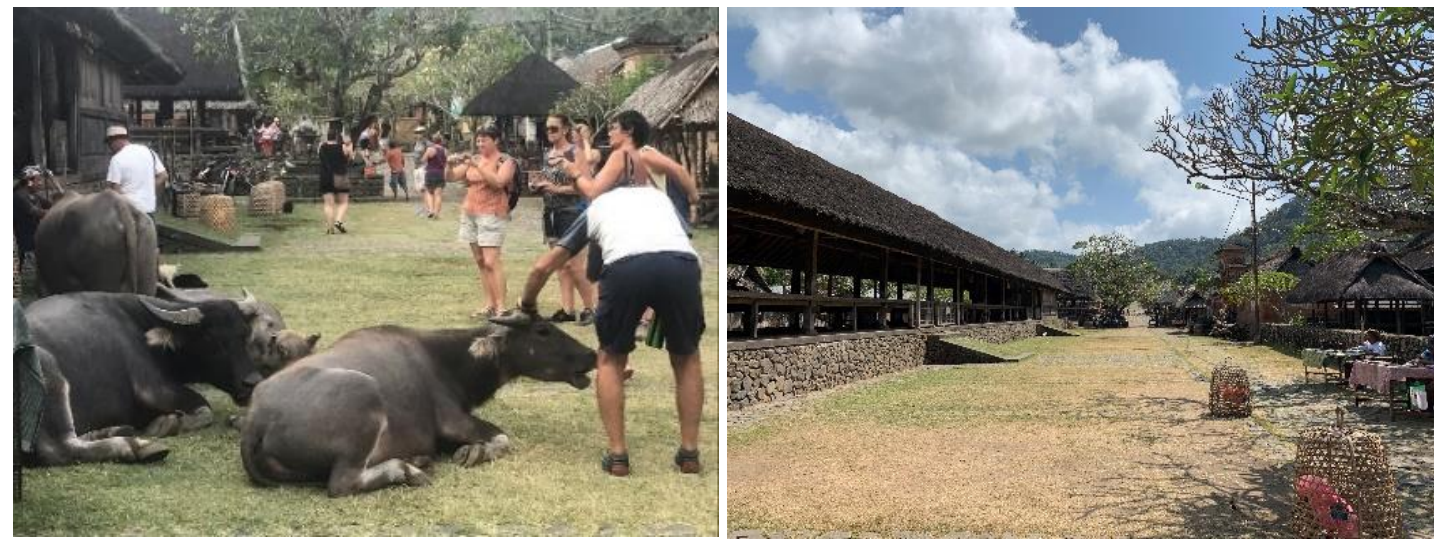

Figure 13. Open space plaza in Tenganan Pegringsingan Customary Village

Table 1. Social activities and composition - property

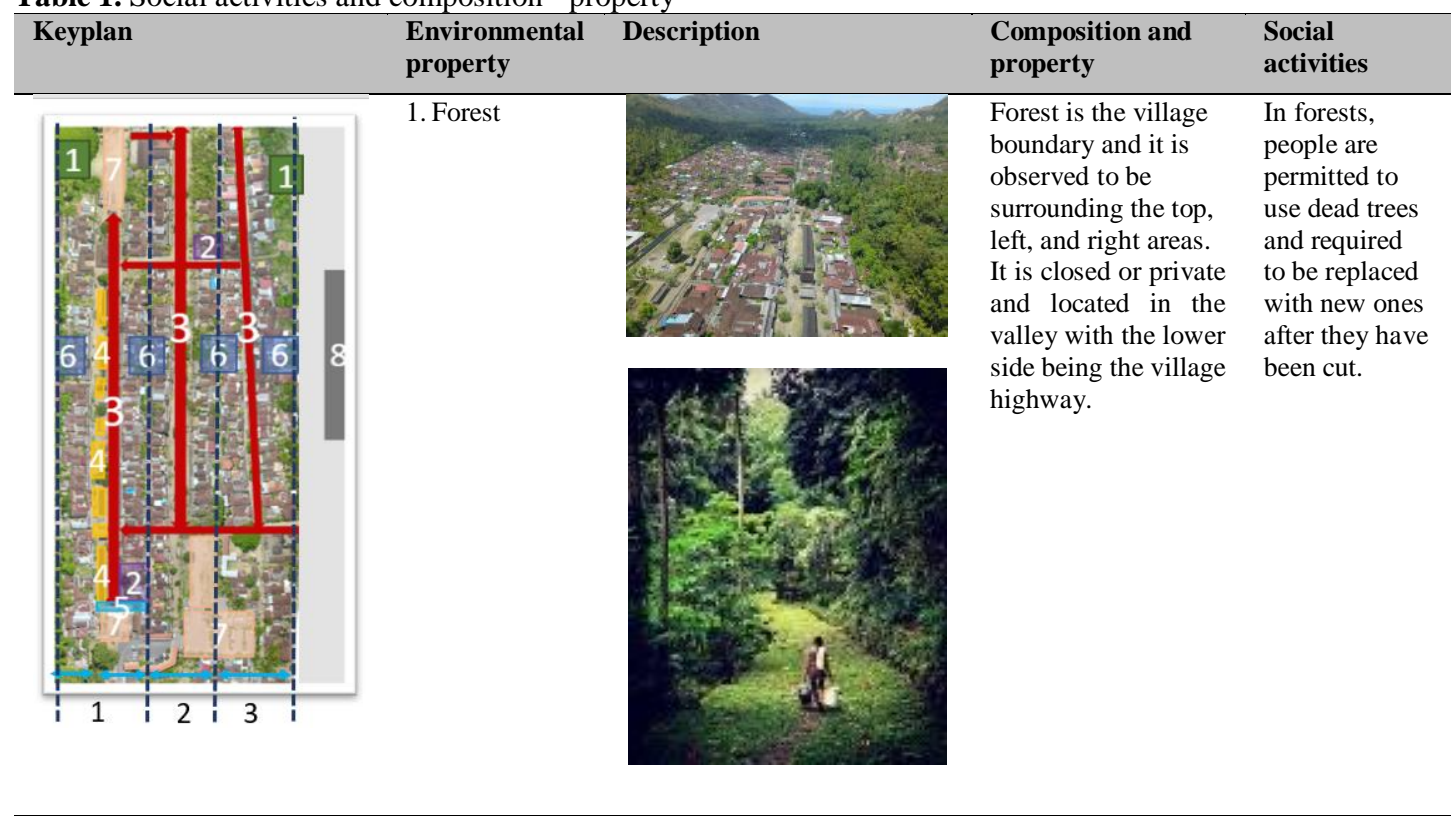




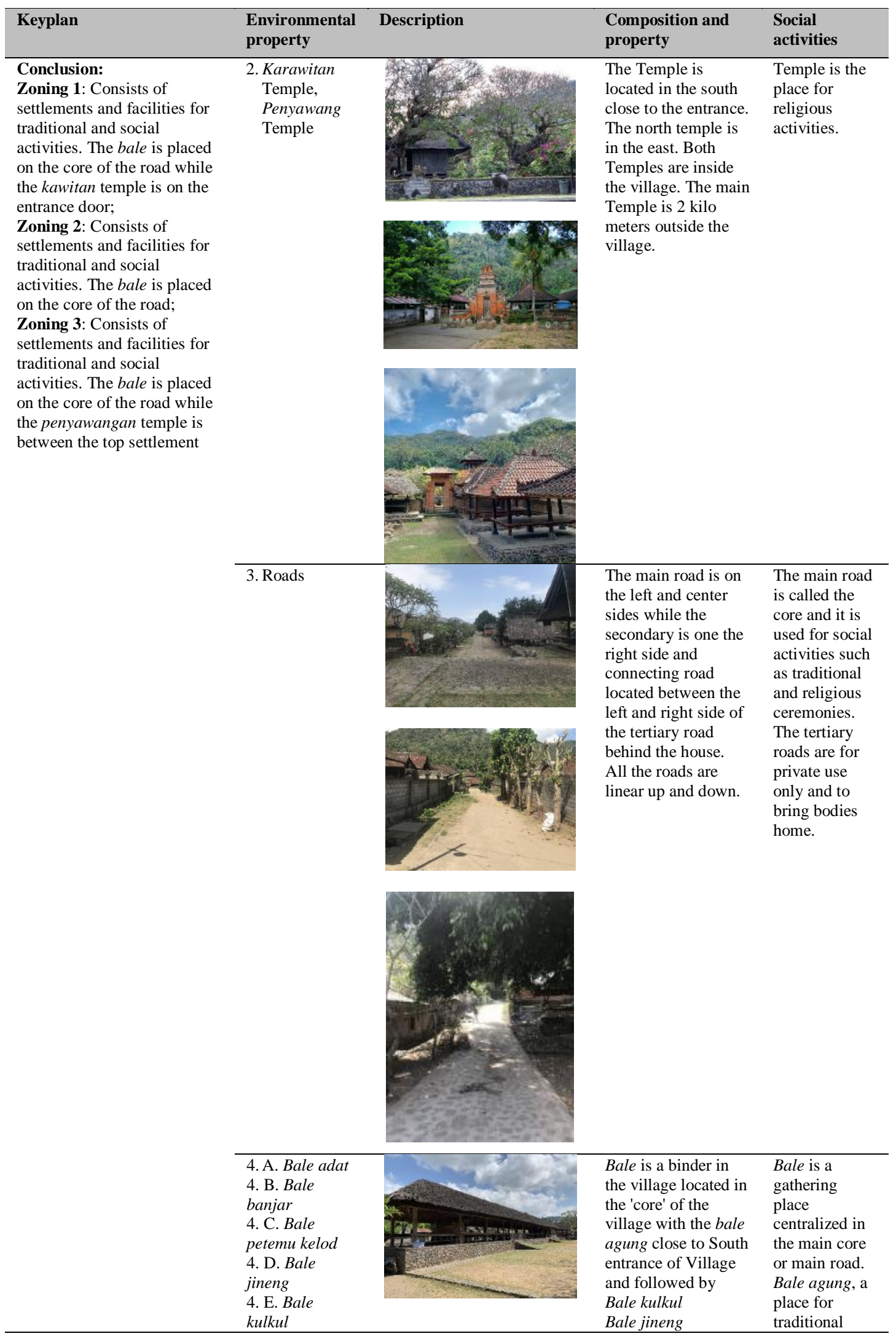




\begin{tabular}{|c|c|c|c|c|}
\hline Keyplan & $\begin{array}{l}\text { Environmental } \\
\text { property }\end{array}$ & Description & $\begin{array}{l}\text { Composition and } \\
\text { property }\end{array}$ & $\begin{array}{l}\text { Social } \\
\text { activities }\end{array}$ \\
\hline & $\begin{array}{l}\text { 4. F. Bale } \\
\text { glebeg }\end{array}$ & & $\begin{array}{l}\text { Bale glebek } \\
\text { Bale banjar } \\
\text { Bale petemu kelod }\end{array}$ & $\begin{array}{l}\text { village } \\
\text { gathering. } \\
\text { Bale kulkul, a } \\
\text { place to signal } \\
\text { a gathering. } \\
\text { Bale jineng, a } \\
\text { place to save } \\
\text { the harvest. } \\
\text { Bale glebek a } \\
\text { place for } \\
\text { custom } \\
\text { equipment. } \\
\text { Bale banjar a } \\
\text { place for a } \\
\text { village } \\
\text { meeting. } \\
\text { Bale petemu } \\
\text { kelod a place } \\
\text { for young } \\
\text { people to } \\
\text { gather. }\end{array}$ \\
\hline & $\begin{array}{l}\text { 5. Entrance } \\
\text { gate of } \\
\text { karang }\end{array}$ & $=$ & $\begin{array}{l}\text { There is no gate in } \\
\text { the village but an } \\
\text { entrance marked } \\
\text { with a height above } \\
\text { the ground level. } \\
\text { There is no angkul } \\
\text { and the house } \\
\text { entrance is in the } \\
\text { form of a door } \\
\text { placed at the bottom } \\
\text { of the village. }\end{array}$ & $\begin{array}{l}\text { It is possible } \\
\text { for residents to } \\
\text { enter the } \\
\text { house through } \\
\text { the main road } \\
\text { or tertiary road } \\
\text { at the back } \\
\text { door. } \\
\text { Tourists are } \\
\text { only allowed } \\
\text { to pass } \\
\text { through the } \\
\text { door from the } \\
\text { bottom of the } \\
\text { village. }\end{array}$ \\
\hline
\end{tabular}




\begin{tabular}{|c|c|c|c|c|}
\hline Keyplan & $\begin{array}{l}\text { Environmental } \\
\text { property }\end{array}$ & Description & $\begin{array}{l}\text { Composition and } \\
\text { property }\end{array}$ & $\begin{array}{l}\text { Social } \\
\text { activities }\end{array}$ \\
\hline & 6. Karang & 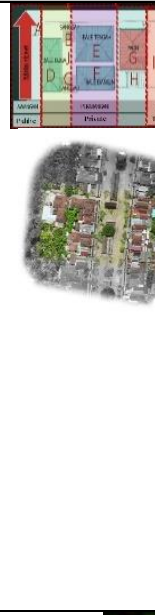 & $\begin{array}{l}\text { The karang is } \\
\text { positioned on either } \\
\text { the left or right side } \\
\text { facing the main road. } \\
\text { It is divided into } 3 \\
\text { zones which are the } \\
\text { public, semi-public, } \\
\text { and private zones. }\end{array}$ & $\begin{array}{l}\text { Karang is } \\
\text { private and the } \\
\text { activities } \\
\text { inside the } \\
\text { house are } \\
\text { hidden from } \\
\text { the outside or } \\
\text { the neighbors. } \\
\text { It is made up } \\
\text { of sanggah, } \\
\text { bale buga, } \\
\text { central bale, } \\
\text { bale sakenem, } \\
\text { and paon. } \\
\text { Each being } \\
\text { used for } \\
\text { different } \\
\text { family custom } \\
\text { programs. }\end{array}$ \\
\hline & $\begin{array}{l}\text { 7. Spaces } \\
\text { outside the } \\
\text { site }\end{array}$ & t & $\begin{array}{l}\text { The outer spaces } \\
\text { including roads and } \\
\text { plaza are formed by } \\
\text { the series of massive } \\
\text { building walls } \\
\text { (penyengker). }\end{array}$ & $\begin{array}{l}\text { The open } \\
\text { spaces are } \\
\text { used for } \\
\text { religious } \\
\text { ceremonies } \\
\text { and village } \\
\text { customary } \\
\text { activities. }\end{array}$ \\
\hline & 8. Tomb & & $\begin{array}{l}\text { The tomb is located } \\
\text { on the right side } \\
\text { outside the village } \\
\text { environment }\end{array}$ & $\begin{array}{l}\text { It serves as the } \\
\text { village's burial } \\
\text { site }\end{array}$ \\
\hline
\end{tabular}

\section{The scope of the site (tapak)}

The scope of the site or tapak relating to the karang was discovered by the architectural anatomy to be consisting of buildings with (1) entrance, (2) sanggah or pemerejan (a place for worship), (3) bale buga, (4) middle bale, (5) bale dangin or house, (6) paon or kitchen, (7) and outer space (figure 14, figure 15).

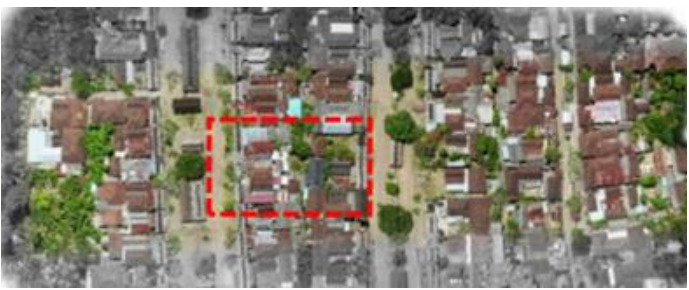

Figure 14. Karang of Tenganan Pegringsingan Customary Village
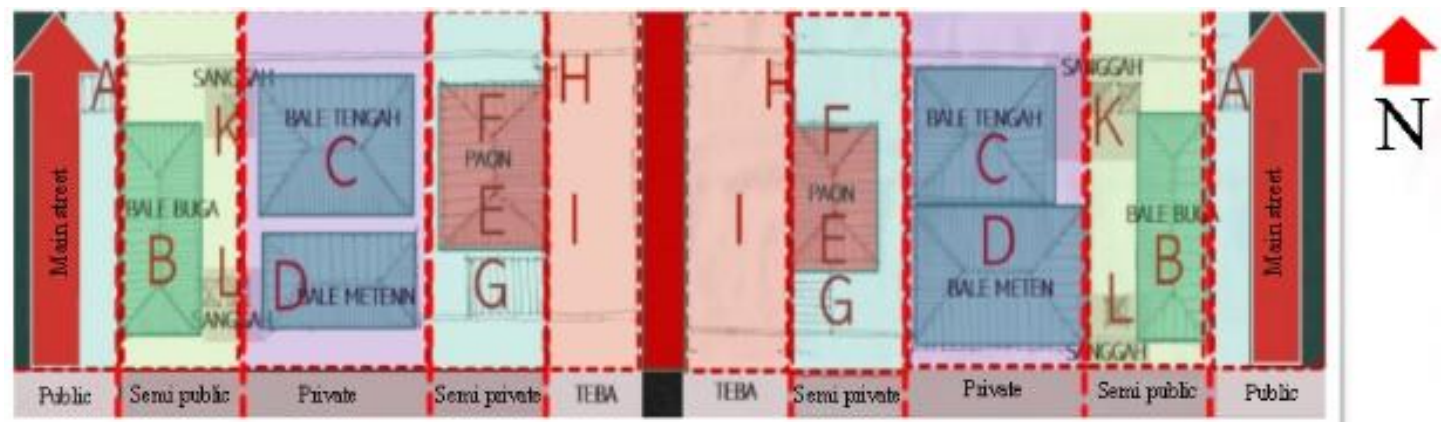

Figure 15. The scope of the site in a karang zone

The karang zone in the village is divided into three zones which are public or awangan, private or pekarangan, and semi-private or teba.
There is no knowledge of angkul which is used in entering the site of the house in the village except for the use of a wooden panel door. Every 
karang has entrances from the front and back with the doors located in a straight line or on the same axis in comparison with human body philosophy which shows income and expenditure are in one line. However, the middle bale is located between the two doors to block the direct view.
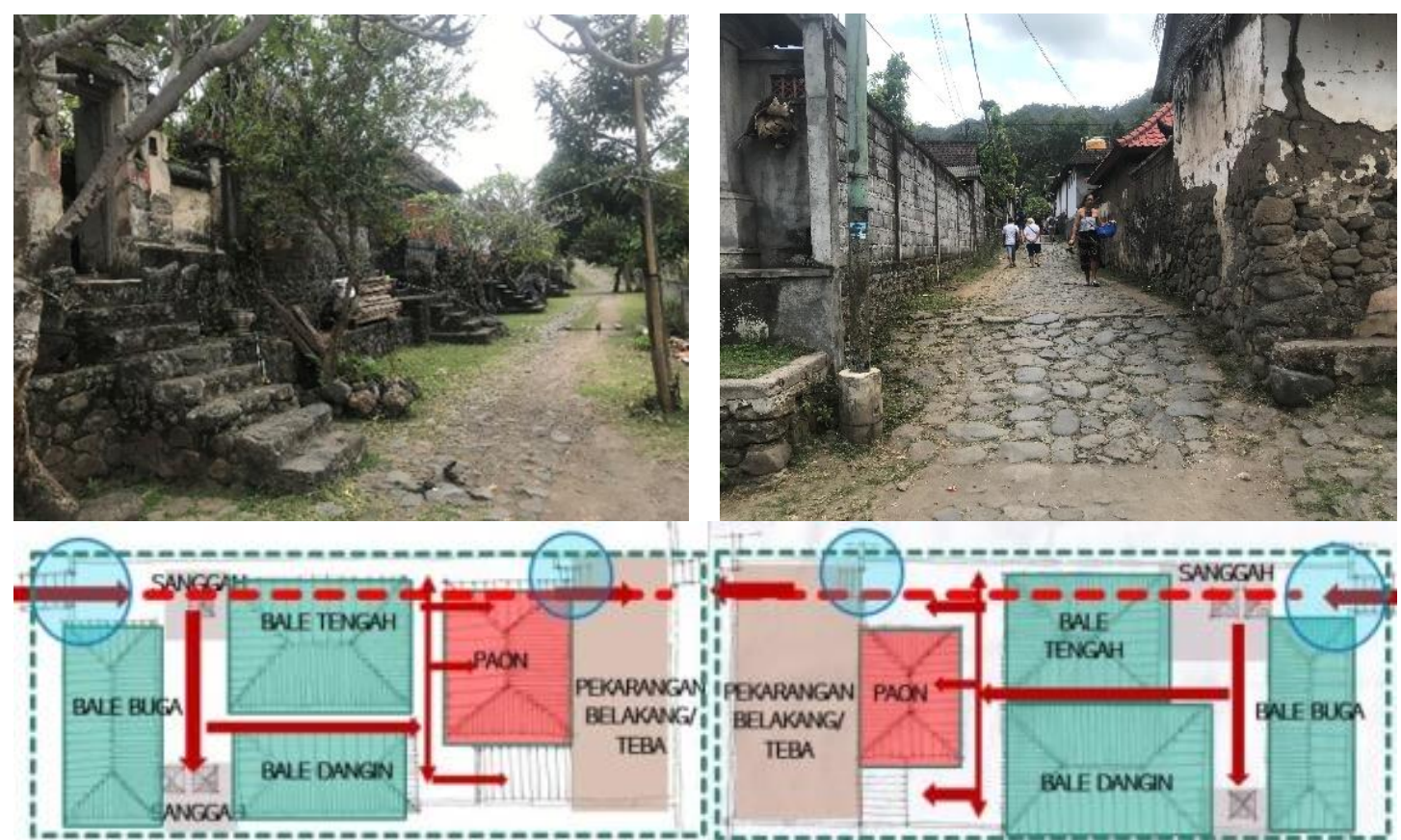

Figure 16. Karang entrance

Every karang in the village has 2 sanggah or place for worship which are located at the top or North facing down or South and vice versa. The top is used to pray to "Ida Sang Hyang Widhi" while the bottom is for praying to the ancestors.

The sanggah is also located between the bale buga and bale dangin to form an open and
From the structural and composition perspective, the karang door is $90-120 \mathrm{~cm}$ high from the ground surface and this means it is higher than the road. This height, however, reduces towards the top or North. The karang is also observed to be very private and closed (figure 16).

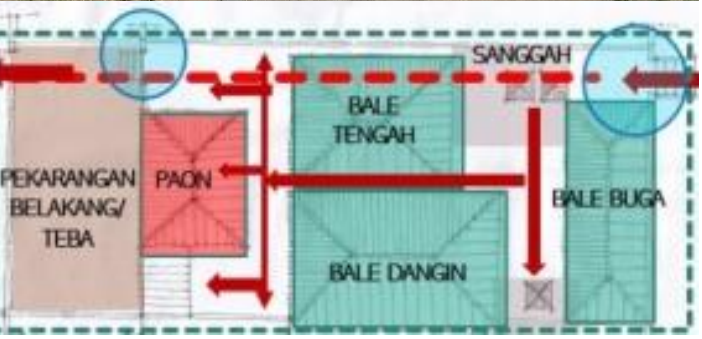

important space in the site. The area is usually considered sacred and used for several family religious traditions such as teeth cutting, wedding, and death ceremonies. It has a linear concept with upward or North and downward or South directions (figure 17).

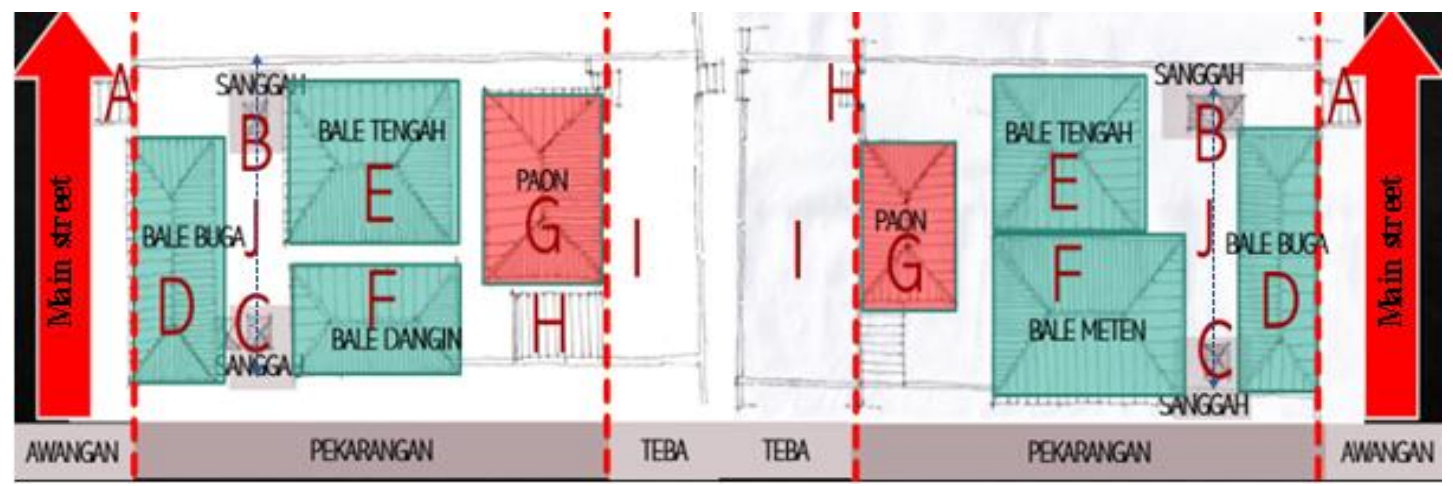




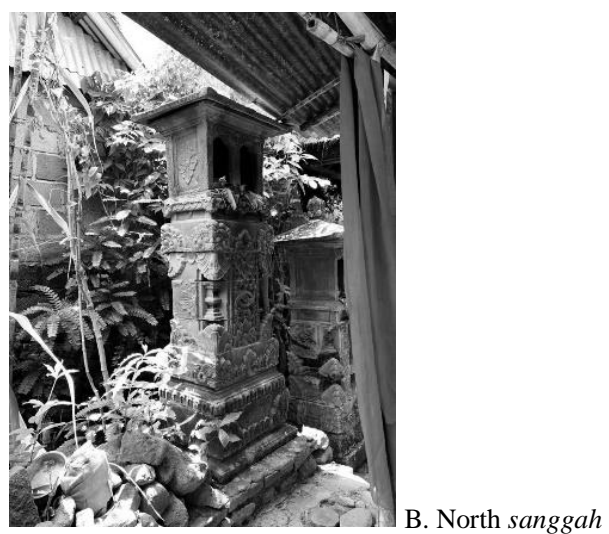

Figure 17. North and South sanggah in karang

The middle bale is in the same axis with the front and back entrance, next to the sanggah, and precisely in front of its entrance. It is located on the top or North side of karang and facing down or Southward, at the left side of bale buga and in

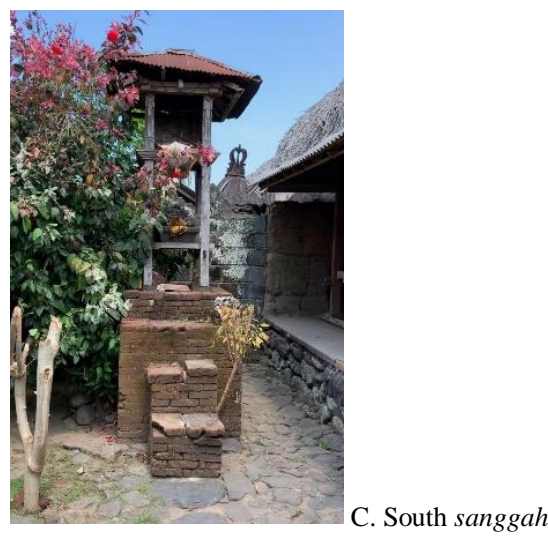

front of the bale dangin. It has also been discovered to be higher than the ground surface.

The karang is also divided into three parts which are the semi-private, private, and semipublic zones. The middle bale is located in the private zone and used for birth and death ceremonies before the body is buried (figure 18).

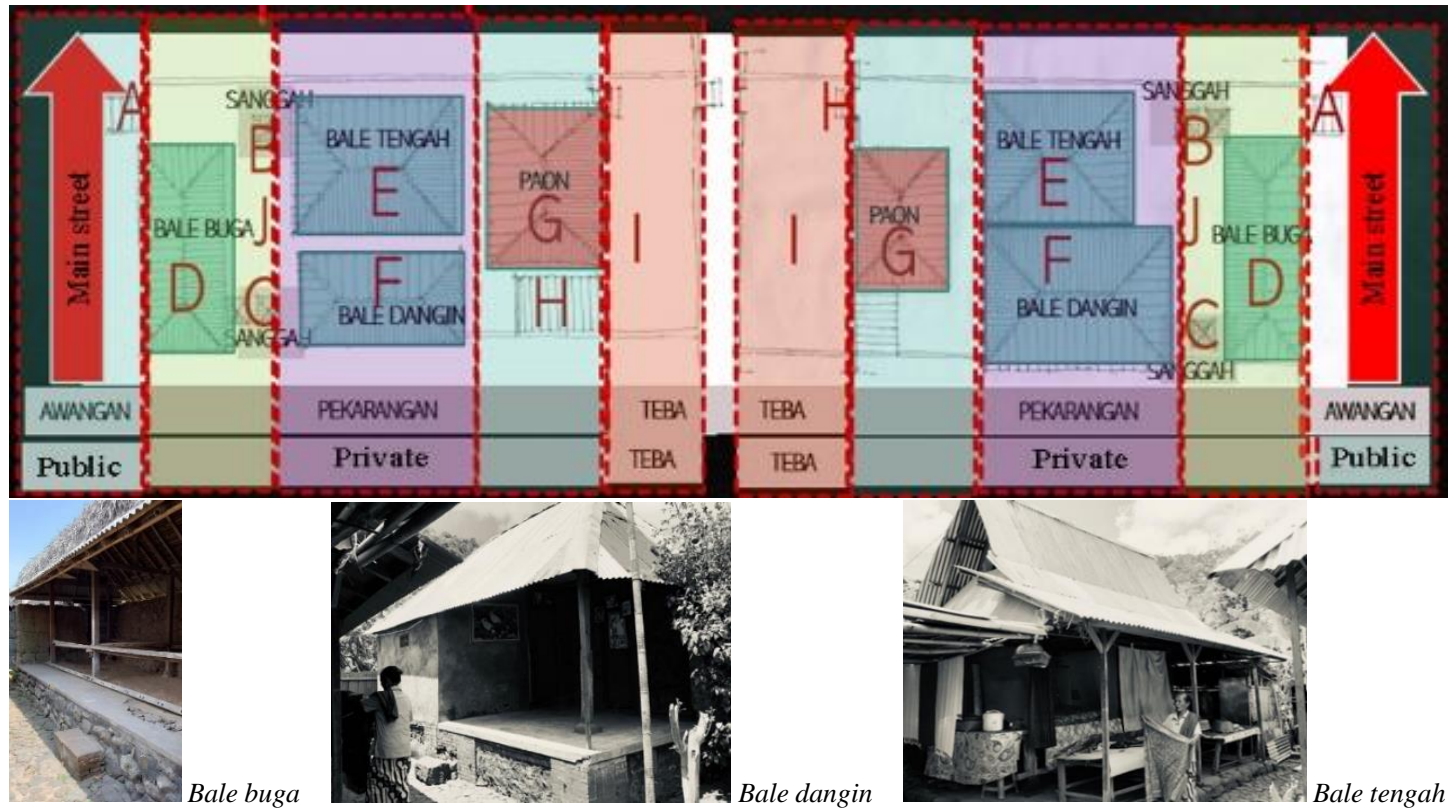

Figure 18. Division of karang zones

The bale dangin or bale meten is the building which is functioning as the residence. It has nine supporting poles (saka sanga) which are used to form the natah or open space in karang. Bale dangin is in the private zone facing the middle bale. Its placement on the left or right side of the bale buga or between it and the service area which is used for washing and cooking is influenced by the entrance.

In a situation the entrance is placed to face the West, the paon or kitchen is located in the East/Kangin attached to the rear wall of the Karang which is in the semi-private zone and next to the back door. Meanwhile, in the case the front door faces East, the paon is located on the western-most side attached to the back wall and next to the back door.

The outer space of the building is open and formed due to the mass composition of the bale dangin, middle bale, and bale buge. This space is 
called an empty space or natah containing a binding (datum) mass. It is an orientation conception involving the formation of a core or plaza using mass units intended for family activities (figure 19).
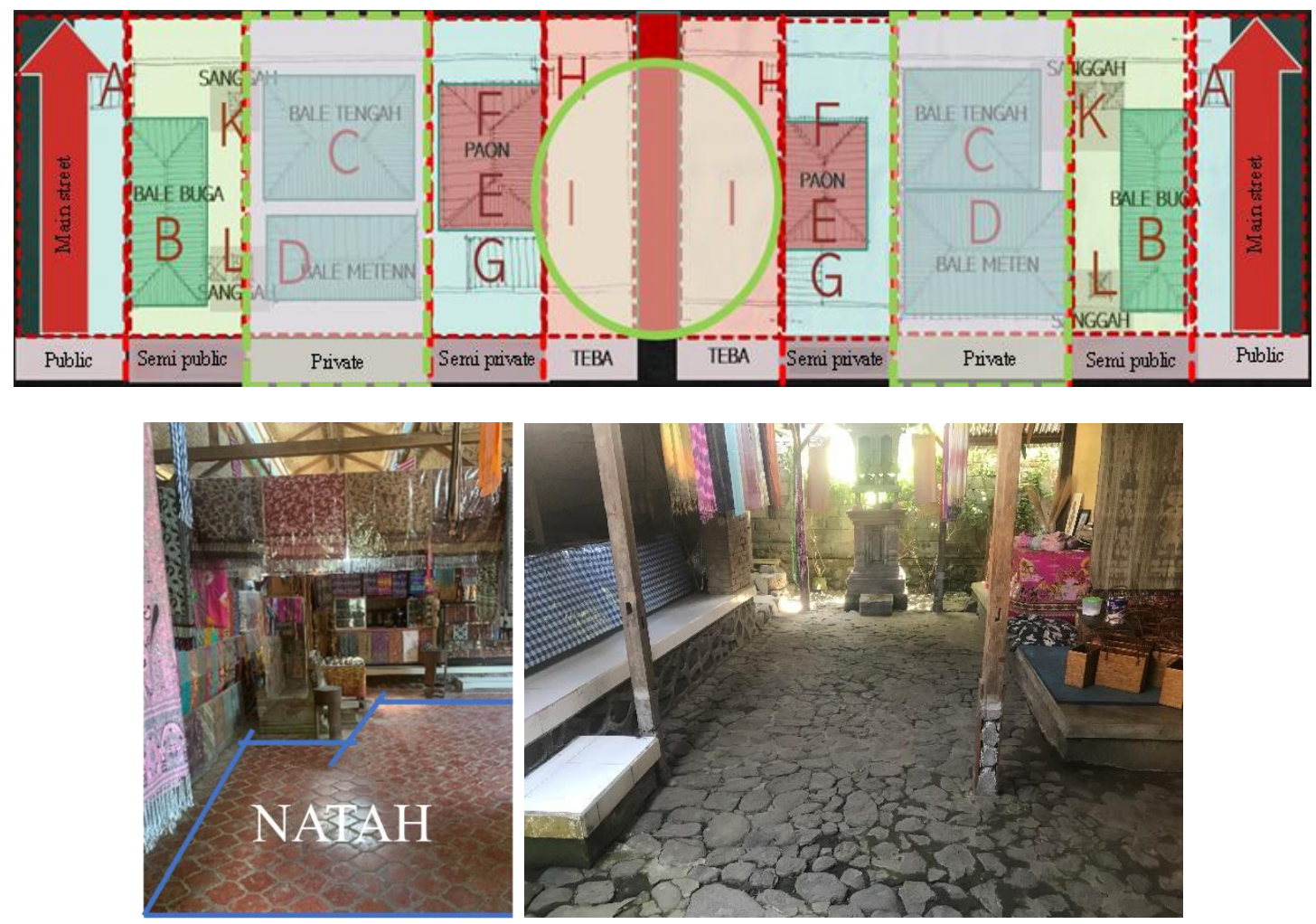

Figure 19. Empty space in karang-natah

Table 1. Composition - property and social activities in the scope of site (karang)

\begin{tabular}{|c|c|c|c|c|}
\hline Keyplan & Site property & Description & $\begin{array}{l}\text { Composition } \\
\text { and property }\end{array}$ & Social activities \\
\hline & $\begin{array}{l}\text { 1. Karang } \\
\text { entrance }\end{array}$ & & $\begin{array}{l}\text { The entrance is } \\
\text { the same as the } \\
\text { common door } \\
\text { of a house. It is } \\
\text { placed on both } \\
\text { left and right } \\
\text { sides facing the } \\
\text { main road. } \\
\text { The karang is } \\
\text { positioned } \\
\text { higher than the } \\
\text { surface of the } \\
\text { main road and } \\
\text { observed to be } \\
\text { lower towards } \\
\text { the north. } \\
\text { The back door } \\
\text { of the house } \\
\text { faces the back } \\
\text { road or Teba and } \\
\text { aligns with the } \\
\text { main door. }\end{array}$ & $\begin{array}{l}\text { The entrance faces } \\
\text { the main road while } \\
\text { the back door faces } \\
\text { the tertiary road } \\
\text { according to the } \\
\text { parable of people in } \\
\text { and out. } \\
\text { There are more } \\
\text { activities in and out } \\
\text { of the house } \\
\text { compared to the back } \\
\text { door. corpse with } \\
\text { The core death is } \\
\text { unreasonable } \\
\text { brought into the } \\
\text { house through the } \\
\text { back door. }\end{array}$ \\
\hline
\end{tabular}


Lydia Dewi Setiawan, Purnama Salura, Bachtiar Fauzy: The relationship between traditional activities and the mass-space pattern in Bali Aga Customary Village society - Tenganan Pegringsingan

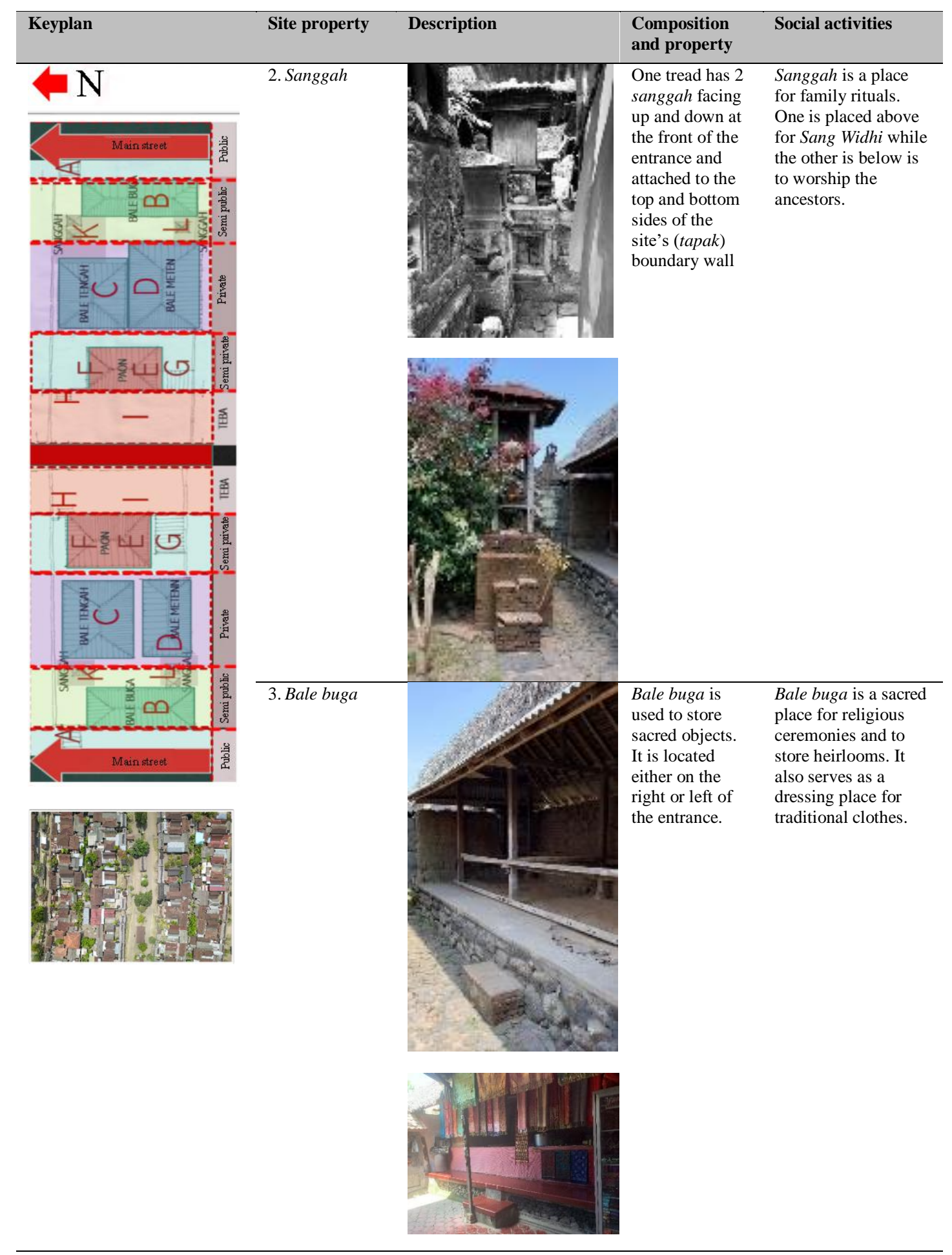




\begin{tabular}{|c|c|c|c|c|}
\hline Keyplan & Site property & Description & $\begin{array}{l}\text { Composition } \\
\text { and property }\end{array}$ & Social activities \\
\hline & 4. Bale tengah & & $\begin{array}{l}\text { This is located } \\
\text { in front of the } \\
\text { door parallel to } \\
\text { the door on the } \\
\text { North side. It } \\
\text { has a height of } \\
\pm 80 \mathrm{~cm} \text { from } \\
\text { the ground and } \\
\text { faces south. It is } \\
\text { in the private } \\
\text { part of the three } \\
\text { zones in } \\
\text { pekarang. }\end{array}$ & $\begin{array}{l}\text { Bale tengah is used } \\
\text { for death ceremonies } \\
\text { and also serves as } \\
\text { men's beds. }\end{array}$ \\
\hline & 5. Bale menten & & $\begin{array}{l}\text { Bale meten is a } \\
\text { dwelling house } \\
\text { located on the } \\
\text { lower side of } \\
\text { the sanggah and } \\
\text { opposite the } \\
\text { bale tengah. It } \\
\text { is also higher } \\
\text { than the floor } \\
\text { surface. }\end{array}$ & $\begin{array}{l}\text { Bale menten is in the } \\
\text { private area and } \\
\text { located at the bottom } \\
\text { of the karang. It is a } \\
\text { living area where all } \\
\text { home activities are } \\
\text { conducted. }\end{array}$ \\
\hline & 6. Paon & & $\begin{array}{l}\text { Paon is located } \\
\text { on the most } \\
\text { right side of the } \\
\text { entrance facing } \\
\text { the road and } \\
\text { also serves as } \\
\text { the exit to the } \\
\text { tertiary road } \\
\text { from the back } \\
\text { door. }\end{array}$ & $\begin{array}{l}\text { Paon is a place for } \\
\text { cooking. }\end{array}$ \\
\hline & 7. Outer space & & $\begin{array}{l}\text { This is an open } \\
\text { space which } \\
\text { serves as the } \\
\text { center and } \\
\text { datum for } \\
\text { buildings within } \\
\text { the site. }\end{array}$ & $\begin{array}{l}\text { It serves as a binder } \\
\text { to all buildings in } \\
\text { Pekarang. It is also } \\
\text { known as empty } \\
\text { space. } \\
\text { It is the center of the } \\
\text { building's position. }\end{array}$ \\
\hline
\end{tabular}

\section{Conclusion}

Tenganan Pegringsingan Village is one of the Bali Aga mountain villages observed to be in line with the Bali Aga tradition.

The relationship between the traditional activities and the mass-space pattern in this village was observed to have produced a significant concept of mass and space patterns based on traditional activities influencing building or mass functions. Moreover, vacant or empty space patterns are formed due to the closed structure of the masses or buildings. This was observed in two places with the first being village settlement environment called awangan which is a public facility for religious and traditional ceremonies. The second is a more private empty space on the site or karang called natah formed between the composition of surrounding building 
mass and used for family religious and customary traditions. The village also has a linear road axis from the bottom to the top or North to South with a series of sites facing the main or middle or core road. The karang is oriented towards sunrise and sunset which is East and West and also has a grid pattern. Furthermore, the village is divided into three zones based on the Banjar line which are the West Customary Banjar (Kauh) or public, middle Customary Banjar or semi-private, and the East Customary Banjar Pande (Kangin) or private. The sites are also divided into semi-public or awangan, private or pekarangan, and semiprivate or teba zones. Sanggah was observed to be located on the North and South sides which is a semi-public area while open space patterns are formed by the linear and North-South oriented road axis. The village hierarchy is higher to the north and lower on the south.

It is possible to use these findings as a reference to maintain mass order and village space in Bali villages as an identity of Bali Mula or Bali Aga. They also serve as the model and basic concepts of mass and space structuring patterns in designing a new village or new settlement in Bali.

The application of these findings in other cases with similar characteristics, however, requires adjustment of the steps in line with the changes observed.

\section{References}

Agusintadewi, Ni Ketut, and I Wayan Yuda Manik. 2016. 'Menguak Tradisi Masyarakat Desa Bali Aga Di Kabupaten Bangli: Desa Sekardadi Dalam Jelajah Arsitektur'. Denpasar.

https://simdos.unud.ac.id/uploads/file_penelit ian_1_dir/2aa98a4674ed072fa4db08996435d e12.pdf.

Antariksa. 2018. Arsitektur Dalam Dinamika Ruang Bentuk Dan Budaya. Yogyakarta: Cahaya Atma Pustaka.

Bali Teen Adventure. 2015. 'Masyarakat Bali Aga Dan Sejarah Asal Muasal Penduduk Bali'. Bali Teen Adventure. 2015. http://baliteenadventure.blogspot.com/2015/06/masyarakatbali-aga-dan-sejarah-asal.html.

Budihardjo, Rachmat. 2019. 'Pengaruh Pariwisata Pada Adaptasi Fungsi, Bentuk Dan
Ruang Arsitektur Puri, Studi Kasus: Puri Saren Agung Ubud'. ARTEKS : Jurnal Teknik $\begin{array}{llll}\text { Arsitektur } \quad 4 & \text { (1): 63-72. }\end{array}$ https://doi.org/10.30822/arteks.v4i1.80.

Dwijendra, Ngakan Ketut Acwin. 2009. Arsitektur \& Kebudayaan Bali Kuno. Edited by Jiwa Atmaja. Denpasar: Kerjasama CV. Bali Media Adhikarsa [dan] Udayana University Press.

Hidayatun, Maria I., Josef Prijotomo, and Murni Rachmawati. 2014a. 'Arsitektur Nusantara Sebagai Dasar Pembentuk Regionalisme Arsitektur Indonesia'. In Transformasi NilaiNilai Tradisional Dalam Arsitektur Masa Kini, 1-9. Surabaya: Petra Christian University.

http://repository.petra.ac.id/17366/1/Publikas i1_85012_2286.pdf.

Hidayatun, Maria I, Josef Prijotomo, and Murni Rachmawati. 2014b. 'Arsitektur Di Indonesia Dalam Perkembangan Jaman, Sebuah Gagasan Untuk Jati Diri Arsitektur Di Indonesia'. In Ruang \& Tempat Dalam Latar Indonesia. Yogyakarta: Lembaga Sejarah Arsitektur Indonesia dan Fakultas Arsitektur dan Desain Universitas Kristen Duta Wacana. http://repository.petra.ac.id/16632/1/Publikas i1_85012_1436.pdf.

Kumurur, Veronica A., and Setia Damayanti. 2011. 'Pola Perumahan Dan Pemukiman Desa Tenganan Bali'. Sabua: Jurnal Lingkungan Binaan Dan Arsitektur 3 (2): 7-14. https://ejournal.unsrat.ac.id/index.php/SABU A/article/view/246/193.

Menteri Kebudayaan dan Pariwisata RI. 2010. Pedoman Umum Program Nasional Pemberdayaan Masyarakat (PNPM) Mandiri Pariwisata Melalui Desa Wisata. Indonesia. https://www.kemenparekraf.go.id/post/peratu ran-menteri-kebudayaan-dan-pariwisatanomor-pm26um001mkp2010.

Nabakov, Peter, and Pater Nabokov. 1999. 'No TitEncyclopedia of Vernacular Architecture of the Worlde'. Traditional Dwellings and Settlements Review 10 (2): 69-75. https://doi.org/10.2307/23566265.

Noerwidi, Sofwan. 2018. 'Migrasi Autronesia Dan Implikasinya Terhadap Perkembangan Budaya Di Kepulauan Indonesia'. AMERTA 
32

https://doi.org/10.24832/amt.v32i1.374.

$(1)$

Oliver, Paul. 1998. Encyclopedia of Vernacular Architecture of the World. London, England: Cambridge University Press.

Penny, James S. 1987. 'Recent Advances in IndoPaciflc Prehistory. V. N. Misra and Peter Bellwood, Editors. Oxford and IBH Publishing Co., New Delhi, 1985. Xxvi + 525 Pp., Figures, Plates, Tables, References, Index, (Cloth). - Prehistory of the IndoMalaysian Archipelago. Peter'. American Antiquity $\quad 52 \quad$ (3): $\quad$ 665-665. https://doi.org/10.2307/281634.

Runa, I Wayan. 2018. Arsitektur Publik Bali Kuno: Sistem Spasial Desa Pegunungan. Denpasar: Udayana University Press.

Sahroni, Ade. 2012. 'Arsitektur Vernakular Indonesia: Peran, Fungsi, Dan Pelestarian Di Dalam Masyarakat'. Ikatan Ahli Arkeologi Indonesia (IAAI) Menggali Masa Lalu, Pada Masa Kini, Untuk Masa Depan Yang Cerah. 2012.

https://iaaipusat.wordpress.com/2012/03/19/a rsitektur-vernakular-indonesia-peran-fungsidan-pelestarian-di-dalam-masyarakat/.

Salura, Purnama. 2010. Arsitektur Yang Membodohkan. 1st ed. Bandung: CSS Publishing.

. 2018. 'The Philosophy of Architectural Ordering Principles'. International Journal of
Engineering and Technology (UAE) 7 (2.9): 52-55.

https://doi.org/10.14419/ijet.v7i2.9.13346.

Soeriadiredja, Purwadi, and Aliffiati. 2017. 'Napak Tilas Jati Diri Orang Bali Aga'. Sunari Penjor: Journal of Anthropology 1 (1): 4352.

https://ojs.unud.ac.id/index.php/penjor/article /view/34864/21094.

Sumunar, Dyah Respati Suryo, Suparmini, and Sriadi Setyawati. 2017. 'Masyarakat Desa Adat Tenganan Pegringsingan'. Jurnal Penelitian Humaniora 22 (2): 111-24. https://journal.uny.ac.id/index.php/humaniora /article/view/19929/pdf.

Widiastuti. 2018. 'Ketahanan Budaya Masyarakat Bali Aga Dalam Menciptakan Desa Wisata Yang Berkelanjutan'. Jurnal Kajian Bali (Journal of Bali Studies) 8 (1): 93. https://doi.org/10.24843/JKB.2018.v08.i01.p 06.

Yanuarta, I Wayan Aquaris, Pitri Ermawati, and Kusrini Kusrini. 2019. 'Tradisi Mekare-Kare Di Desa Bali Aga Tenganan Pegringsingan Dalam Fotografi Dokumenter'. Spectā: Journal of Photography, Arts, and Media 2 (1): 57-68. https://doi.org/10.24821/specta.v2i1.2468. 